\title{
Virtual Laboratory Based on Discovery Learning to Train an Analyzing-Interpreting Data: A Systematic Review
}

\author{
Trijayanti $\mathrm{P}^{1}$, Nurfina Aznam ${ }^{2}$, Krisma Haryuniati ${ }^{3}$

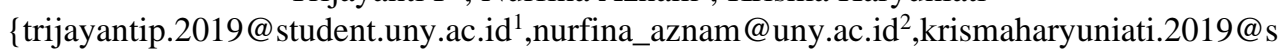 \\ tudent.uny.ac.id $\left.{ }^{3}\right\}$ \\ Science Education Department, Universitas Negeri Yogyakarta, Jl. Colombo No.1, Yogyakarta \\ 55281, Indonesia ${ }^{1}$, Organic Chemistry Department,Universitas Negeri Yogyakarta, Jl. Colombo No.1, \\ Yogyakarta 55281, Indonesia ${ }^{2}$, Social Science Education Department, Universitas Negeri Yogyakarta, Jl. \\ Colombo No.1, Yogyakarta 55281, Indonesia ${ }^{3}$.
}

\begin{abstract}
Virtual laboratories based on discovery learning are an alternative source to support the distance learning process during the current pandemic. The study aims to provide an overview of how virtual laboratories based on discovery learning can be applied to the ability to analyze and interpret student data. The method used is a systematic review. The articles used are from Google Scholar and ERIC, then the search findings are directed to national and international journals published in 2010-2020. The number of articles used was 26 articles based on relevant research sources. The results of the analysis show that a virtual laboratory based on discovery learning can improve students' data analyzing-interpreting abilities through practicum simulations with scientific methods. Experimental simulations are carried out independently so that learning is more than meaningful. Students display data as proof to support their conclusion.
\end{abstract}

Keywords: Virtual laboratory, discovery learning, analyzing-interpreting data abilities.

\section{Introduction}

Advances in information communication and technology, both in commerce, socializing, playing, and learning, have changed the lifestyles of people. These technological advances have penetrated various aspects of life in the 21st century, with no exception in the field of education [1].Currently, the development of science and technology is directed at reaching the objectives of national education. Article 1 of Law No 20 of 2003 on the National Education System aims to set out the objectives of national education, namely to develop the potential of students to have intelligence, personality, and noble character [2]. National education components provide the environment, infrastructure, resources and society [3].

The main factors for attaining education come from the curriculum, educators, and the learning process. Every learning requires a strategy, model, and learning media to give students a positive impression of learning activities. So the students' achievements progress and achieve the demanded national education goals. Approximately advancing the state of science learning, almost all materials require experimental activities to support learning objectives. This is strengthened by findings in several schools that: (1) the condition of school 
laboratory facilities is uneven, generally low in terms of quality and quantity, (2) based on the aspect of the ability of educators, it was found that while the science tools were equipped with block grant funds It turns out that the implementation is rarely carried out only about 1-3 times a semester and takes place in an unstructured and productive process [4]. One of the determinants that influence the success of the laboratory activities is the availability of resources, including materials and equipment, space and appointments, laboratory assistants, and professionals. The availability of adequate resources will support the implementation of laboratory activities. On the other hand, the limitations of vehicles and stocks will lead to ineffective laboratory experiments, so that we need an innovation that can support learning activities [5].

Educational variation in the form of media utilization needs to be done so that students have complete knowledge of the concept of science. Science learning consists of many ideas and principles that are generally abstract. Science learning emphasizes providing direct experience to develop competencies to explore and appreciate the natural surroundings scientifically. Therefore, the approach applied in presenting science learning is to combine process experience and understanding of science products in direct experience. This approach is usually used in the form of experimental activities in the laboratory. However, in reality, learning activities are still overlooked by traditional learning models, straightforward learning with lecture methods and practices in laboratories, which have various obstacles, namely limitations on tools, time, and natural conditions.

There is trust in visualization to understand the concept of science. Students need various visualization elements, one of which is a virtual laboratory, to properly integrate new concepts. The use of virtual laboratories in science learning (1) allows for experimental activities that can be carried out for economic and spatial reasons, (2) allows visualization at microscopic, submicroscopic and symbolic levels, (3) provides submicroscopic dynamic presentations, (4) allows for a deeper understanding, (5) as a student motivation tool [6]. This is following previous research that states that laboratory activities play an important role in supporting scientific research and enabling students to understand practical skills through experiments so that students have a deeper understanding of the material being taught[7]. This occurs in research that claims that the virtual world can (a) increase the mastery of concepts through students; (b) develop the creative thinking skills of students and scientifically master problems; (c) improve skills in the field of ICT without neglecting lab knowledge [8].

The proper learning model is required to bridge and develop students' scientific thinking abilities. The suitable learning model is to apply the discovery learning model. Using the discovery learning model will develop students' abilities because the discovery learning model has stages that can train students' abilities. These stages include Stimulation, Problem Statement, Data Collection, Data Processing, Verification, and Generalization. Discovery learning emphasizes learning, which is a learner. It makes the students more active in learning and searching for material that will be more meaningful learning [9]. Discovery learning is a model where students build their knowledge through an experiment and discover a principle from the experiment results. Building knowledge means that students can identify problems, conduct experiments, collect data, and draw conclusions. From this process, students are expected to acquire new knowledge [10].

Efforts that need to be made to face global challenges in the 21 st century are improving education according to national standards and how the education system complies with standards applied internationally. Therefore, the integration of Science and Engineering Practices (SEPs) based on the Next Generation Science Standards (NGSS) in science learning also needs to be done. NGSS is a framework in K-12 science education that contains a set of 
knowledge (content) and science abilities expected to be comprehended by students in an integrated manner. NGSS was developed collaboratively by 26 US states hosted by the National Research Council (NRC) at the National Academy of Science by developing the K12 framework. NGSS has an innovative structure that combines three main dimensions, namely: Disciplinary Core Ideas (DCI), (SEPs), and Crosscutting Concepts (CCs) into several small maps explicitly settled on a large theme that can be achieved by all students. NGSS has unique characteristics that emphasize three dimensions, which are interrelated and inseparable. These three dimensions are needed for quality science learning. This three-dimensional integration creates a deeper understanding into how scientific knowledge is obtained and understood and how science is connected through various disciplines through concepts that have universal meaning [11].

One of the practices that NGSS has is the Analyzing-Interpreting Data (AID) abilities. AID is a part of the SEPs dimension in NGSS. These dimensions inform design, enable predictions, assess performance, help define/clarify problems, determine cost estimates, and evaluate errors in investigations [12Meanwhile, scientific data obtain data that must be analyzed for meaning because patterns in data are not always clear. NGSS suggests that some very specific types of data analysis and interpretation are found in scientific practice because not all are relevant to student experiences. An order to get better results, consider the limitations of data analysis (for example, measurement error and attempt to improve data accuracy) with tools and technology. Therefore, to identify essential patterns in data, including tabulation, graphic interpretation, visualization, and statistical analysis, a variety of features is provided. Identifying only the source of the investigation error and calculating the certainty of the results [13].The aim of this study is to provide an overview of how virtual laboratory based on discovery learning can improve the data analyzing-interpreting abilities of students.

\section{Method}

This research used a systematic review as a methodology. This method is related to the Covid-19 pandemic situation, which limits researchers in taking data. The number of articles used was 26 articles. Literature comes from several national and international journals through the Google Scholar and ERIC search engines related to research problems and objectives. The collection of literature uses several stages, including (1) creating a question frame for the topic to be reviewed, (2) identifying relevant research, (3) assessing the results of the research that has reviewed, (4) writing the results of the review (5) analyzing and interpreting the research results. The search for journal articles used to be published in the period 2010-2020 uses the title keywords including "virtual laboratory," "discovery learning," "analyzing and interpreting data," which identified and analyzed based on the relevance of journal content and the relevance of research topics [14].

\section{Result and Discussion}

This study begins by searching for journal articles through two online search engines source; there are Google Scholarand Education Resources Information Center (ERIC). Based on two online search engines source, it found that Google scholar has a much higher number 
of ERIC. However, if we look at the quality of the articles ERIC are higher than Google Scholar. Based on the papers have gone through the screening stage, the next step is to answer the questions that have to ask.

\subsection{Virtual Laboratory}

A virtual laboratory is a system that can be used to support practicum that runs conventionally through simulation [15]. Thus, the virtual laboratoryis a possible means of supporting students' interactive learning experience [16]. The features contained in the Virtual laboratory program consist of various formats, including text, hypertext, sound, images, animation, video, and graphics [17]. Virtual laboratory includes tutorials, simulations, evaluation, and virtual program laboratory equipped recording systems capable of storing participant data [18]. The content contained in the virtual laboratory consists of text, graphics, simulations, and animations [19]. The virtual laboratory can improve students' understanding of a complicated and abstract [20]. Besides, virtual laboratories can direct students to carry out several scientific activities, such as interpreting, predicting, applying concepts, planning research, communicating results, and asking questions [21].

Virtual laboratories improve students' practical experience in learning, are more economical, minimize the dangers of real laboratories, and are not tied to geographic location and time [22]. A more detailed explanation of the advantages of virtual laboratory[23] is as follows :

1) Diminished time constraints, if there is not sufficient time to teach all students in the laboratory until they understand

2) Defeat geographic boundaries, if there are students who live far from school

3) Economical, does not require laboratory buildings, vehicles, and materials as in traditional laboratories

4) Advance the experiment's quality because it allows it to be repeated and clarifies laboratory measurement uncertainties.

5) Enhancing the effectiveness of learning because students will spend more time doing lab run frequently

6) Gain security and safety because it does not interact with real and dangerous tools and materials.

The advantages of virtual laboratories are that they can improve students' mastery of concepts, improve creative thinking abilities and scientific problem solving, and develop ICT abilities without neglecting laboratories knowledge. Whereas the weakness of the virtual laboratoryis that students must be connected to the internet or use a computer to simulate a practicum, lack of experience in a real laboratory, so that students are confused in assembling or operating tools in the virtual laboratory, and do not provide real practical experience [24].

Virtual laboratory product development results are: (1) the product is equipped with a pre-test to support the readiness of the students regarding the material will stimulate and posttest to measure the level of achievement of student understanding after using the product; (2) the product is equipped with particulate visualization that supports students' understanding of concepts that contain representations up to the sub-microscopic level; (3) the product can be used linearly or non-linearly by selecting the practicum menu to be simulated; (4) efficiency of tools, materials, and time even though practicum simulations are carried out as often as students want. The weaknesses of the virtual lab development results include: (1) the product can only run optimally on smartphones based on Android with version 5.0 (Lollipop) -7.0 (Nougat); (2) the sharpness of the color displayed on the product depends on the resolution/pixel density of the smartphone used [25]. 
Based on the description above, the Virtual laboratoryis an interactive media that can visualize learning concepts in practicum activities through simulations. The features contained in the virtual laboratory is in the form of work steps tutorials, animated images, videos, hyperlinks, graphics, evaluation, and recording systems to save student data.

\subsection{Discovery Learning Model}

Discovery learning is a model that emphasizes the importance of understanding concepts, meanings, and relationships through an intuitive process to conclude. Students are actively involved, especially in mental processes, to find several concepts and principles through observation, classification, measurement, prediction, and determination [26]. Discovery learningis a model that directs students to discover concepts through various information or data obtained through observation or experiment [27].

The characteristics of the discovery learning model are (1) learner-centered; (2) investigate and resolve problems to create, connect, and generalize knowledge; (3) connecting new knowledge and existing knowledge. The steps for applying the discovery learningmodel are (1) fixing the learning objectives; (2) identify the characteristics of students; (3) determine the subject matter; (4) determine the topics that must be studied inductively; (5) developing materials by providing examples, illustrations, assignments, etcetera. For students to learn; (6) arranging lesson topics from simple to complex, from concrete to abstract, from enactive, iconic to symbolic stages; and (7) assessing students' process and learning outcomes. There are procedures that must be used in applying the discovery learning model, namely (a) stimulation; (b) problem statement (problem identification); (c) data collection; (d) dataprocessing; (e) verification (proof); and (f) generalization (draw conclusions) [1].

The advantage of discovery learning is that students are active in learning activities because they think and use the ability to find the final result. Students understand the learning material because they experience the process of finding it themselves. That which is obtained in this way is long remembered. The process of finding itself generates a sense of satisfaction. This inner satisfaction encourages wanting to get more findings so that the interest in learning increases. Students who acquire knowledge by discovery will be better able to transfer their knowledge to various contexts. In discovery learning, there are also obstacles faced by students. This obstacle is a drawback in discovery learning. The obstacles faced, for example, require a more extensive learning time than learning to accept.

\subsection{Analyzing-Interpreting Data Abilities}

There obtain a type of devices that can be used in the practice of analyzing and interpreting data. These devices include a table, graphs, mathematics, computer-based visualization tools, and statistical analysis techniques. Each device provides a different perspective on the relationship between the data that may be more or less efficient in dealing with the investigation or design questions specific [28]

Scientific research create data that should be analyzed for meaning. Scientists use various tools, including tabulation, graphical interpretation, visualization, and statistical analysis, to identify essential data features and patterns, declaring that data do not converse on an annual basis. The error reference is identified and certainty is calculated. Modern technology makes it possible and generate large data sets, providing many secondary sources for analysis [11].

How to analyze and interpret the data as follows: 
1) Systematic data analysis to look for salient patterns or to test whether the data is consistent with the initial hypothesis.

2) Notice when the data is in conflict with expectations and consider what revisions are needed in the initial model.

3) To organize, summarize, and display data, apply spreadsheets, databases, tables, charts, statistics, mathematics, and information technology and computers, and explore the relationships between variables, especially those representing input and output.

4) Assess, using appropriate grade-level mathematical and statistical techniques, the conclusions drawn from any data set.

5) Identify patterns in the data that suggest a relationship exciting further. Distinguish between relationships between causal and correlational.

6) Collect data on physical models and assess for design under various conditions

There are four aspects of analyzing-interpreting data: presenting data, organizing data, interpreting data, and summarizing data. Each indicator of data analysis-interpretation ability can be seen in the table below.

Table 3.1 Indicators of Analyzing-interpreting Data Abilities

\begin{tabular}{|c|c|c|}
\hline No. & Aspect & Indicators \\
\hline 1 & Display data & $\begin{array}{l}\text { Display data in the form of tables, diagrams, or } \\
\text { charts }\end{array}$ \\
\hline 2 & Organizing data & $\begin{array}{l}\text { Choose the appropriate data } \\
\text { Group similar data }\end{array}$ \\
\hline $\begin{array}{l}3 \\
4\end{array}$ & $\begin{array}{l}\text { Interpret data } \\
\text { summing up the data }\end{array}$ & $\begin{array}{l}\text { Describe data } \\
\text { Summing up the data }\end{array}$ \\
\hline
\end{tabular}

\section{Conclusion}

Virtual laboratory based on discovery learning can improve students' data analyzinginterpreting abilities through practicum simulations with scientific methods. Experimental simulations are carried out independently so that learning is more than meaningful. Students display data as proof to support their conclusion. The virtual laboratory has features that can visualize the concepts through a simulation like images, videos, graphics, hyperlinks, animation, evaluation, and recording systems for storing student data.

\section{References}

[1] Darmadi H. 2019. Pengantar Pendidikan Era Globalisasi: Konsep Dasar,Teori,Strategi dan Implementasi Dalam Pendidikan Globalisasi. An1mage.

[2] Depdiknas. 2003. Undang-Undang RI No.20 Tahun 2003 Tentang Sistem Pendidikan Nasional.

[3] Munirah. 2015. Sistem Pendidikan di Indonesia: antara Keinginan dan Realita. Jurnal Pendidikan Dasar Islam 2 (2) 233-245.

[4] Supriatno B. 2013. Pengembangan Program Perkuliahan Pengembangan Praktikum Biologi Sekolah Berbasis ANCORB untuk Mengembangkan Kemampuan Merancang dan Mengembangkan Desain Kegiatan Laboratorium. Disertasi tidak diterbitkan. Bandung: Sekolah Pascasarjana Program Studi IPA Universitas Pendidikan Indonesia

[5] Gunawan, Harjono A, Sahidu H, \& Herayanti L. 2017. Virtual Laboratory of Electricity Concept to Improve Prospective Physics Teachers Creativity. Jurnal Pendidikan Fisika Indonesia, 13(2)102111. Universitas Mataram, Indonesia. 
[6] Herga, N. R., Grmek, M. I., \& Dinevski, D. 2014. Virtual laboratory as an element of visualization when teaching chemical contents in science class. Turkish Online Journal of Educational Technology, 13(4), 157-165

[7] Aljuhani K, Sonbul M, Althabiti M, \& Meccawy M. 2018. Creating a Virtual Science Lab (VSL): The Adoption of Virtual Labs in Saudi Schools. Smart Learning Environments, 5(16).

[8] Hermansyah H, Gunawan G, \& Herayanti L. 2015. Pengaruh Penggunaan Laboratorium Virtual Terhadap Penguasaan Konsep dan Kemampuan Berpikir Kreatif Siswa pada Materi Getaran dan Gelombang. Jurnal Pendidikan Fisika Dan Teknologi, 1(2)97.

[9] Tumurun SW,Gusrayani D, Jayadinata AK. 2016. Pengaruh Model Pembelajaran Discovery Learning Terhadap Keterampilan Berpikir Kreatif Siswa Pada Materi Sifat-Sifat Cahaya. Jurnal Pena Ilmiah, 1 (1). Program Studi PGSD Kelas UPI Kampus Sumedang.

[10] Putrayasa. 2014. Pengaruh Model Pembelajaran Discovery Learning Dan Minat Belajar Terhadap Hasil Belajar Ipa Siswa. Jurnal Mimbar PGSD Universitas Pendidikan Ganesha. 2(1)2-11.

[11] Next Generation Science Standards. 2013. Next Generation Science Standards: For States, By States. Volume 1: The Standards-Arranged by Disciplinary Core Ideas and Topics. Washington, DC: The National Academies Press.

[12] National Research Council. 2012. A Framework for K-12 Science Education: Practices, Crosscutting Concepts, and Core Ideas. Washington, DC: The National Academies Press.

[13] The NGSS Lead States. 2013. Next Generation Science Standards: For States, By States (Appendix F-Science and Engineering Practices). Achieve, Inc. on Behalf of the Twenty-Six States and Partners That Collaborated on the NGSS, November, 1-103.

[14] Khan KS, Kunz R, Kleijnen J \& Antes G. 2003. Five steps to conducting a systematic review. Journal of the Royal Society of Medicine, 3, 118-121.

[15] Jaya H .2013. Pengembangan laboratorium virtual untuk kegiatan paraktikum dan memfasilitasi pendidikan karakter di SMK. Jurnal Pendidikan Vokasi, 2(1), 81-90.

[16] Polly P, Marcus N, Maguire D, Belinson Z, \& Velan G M. 2014. Evaluation of an adaptive virtual laboratory environment using Western Blotting for diagnosis of disease. BMC medical education:14-222.

[17] Rasyida N, Tapilouw F S, \& Priyandoko D. 2015. Efektivitas pengembangan praktikum virtual untuk meningkatkan kemampuan berpikir kritis dan sikap ilmiah siswa SMA pada konsep metagenesis tumbuhan lumut dan paku. Prosiding seminar Nasional Pendidikan biologi. Universitas Muhammadiyah Malang.

[18] Ratamun M and Osman K. 2018. The Effectiveness Of Virtual Lab Compared To Physical Lab In The Mastery of Science Process Skill For Chemistry Experiment. The problem of education in the 21 st century. 76 (4)544-560.

[19] Hussaini S J and ChenS. 2019. Effects of guided inquiry virtual and physical laboratories on conceptual understanding, inquiry performance, scientific inquiry self-efficacy, and enjoyment. Physical Review Physics Education Research, 15(1)10119.

[20] Maulana A I. 2018. Penerapan Perangkat Pembelajaran Berbasis Laboratorium Virtual Pada Pencapaian Hasil Belajar. April, 16-22.

[21] Lynch T and Ghergulescu I. 2017. Review of Virtual Labs As the Emerging Technologies for Teaching Stem Subjects. INTED2017 Proceedings, 16082-6091.

[22] Nirwana R R 2016. Pemanfaatan Laboratorium Virtual Dan E-Reference Dalam Proses Pembelajaran Dan Penelitian Ilmu Kimia. Phenomenon : Jurnal Pendidikan MIPA, 1(1)115.

[23] Masri M, Hidayati H, and Davina Y. 2018. The Development of Virtual Laboratory Using ICT for Physics in Senior High School. IOP Conference Series: Materials Science and Engineering, 335(1).

[24] Muchson M, Munzil, Winarni B E, Agusningtyas D. 2019. Pengembangan Virtual Lab Berbasis Android Pada Materi Asam Basa Untuk Siswa SMA. Jurnal Pembelajaran Kimia, 4(1)51-64.

[25] Kristin F and Rahayu D. 2016. Pengaruh Penerapan Model Pembelajaran Discovery Learning Terhadap Hasil Belajar Ips Pada Siswa Kelas 4 Sd. Scholaria: Jurnal Pendidikan Dan Kebudayaan, 6(1)84. 
[26] Cintia N I, Kristin F and Anugrahaeni I. 2018. Penerapan Model Pembelajaran Discovery Learning Nichen Irma Cintia , 2 Firosalia Kristin \& 3 Indri Anugraheni Universitas Kristen Satya Wacana Increasing Students ' Thinking Creative Ability And. Perspektif Ilmu Pendidikan, 32(1) 69-77.

[27] Schwarz C. 2018. Modified Guided Discovery Model: A conceptual Framework for Designing Learning Model Using Guided Discovery to Promote Student's Analytical Thinking Abilities Modified Guided Discovery Model: A conceptual Framework for Designing Learning Model Using Guide.

[28] Schwarz, Cristina V, Passmore, Cynthia, Reiser, Brian J. 2017. Helping Students make sense of The World Using Next Generation Science And Engineering Practices. NSTA Press. Google book hal.159-163. 